\title{
A Comparative Study on Heroism in Shooter and Water Margin
}

\author{
Xiaohong Wei \\ School of Literature and Law, Sichuan Agricultural University, Ya'an, Sichuan Province, China \\ Email: ongwx126@yahoo.com.cn \\ Jian Xu \\ School of Literature and Law, Sichuan Agricultural University, Ya'an, Sichuan Province, China
}

\begin{abstract}
Hero has constantly been an important theme of American commercial movies, which have been swarming into every corner of the world. Those movies focusing on heroism have already become the dominance of modern movie market. Individual heroism as the logo of commercial movies has become the quintessence and soul of Hollywood movies. Just as the freedom and democracy characterize the United States, so is the case with individual heroism which has shaped Hollywood movies. On the other hand, the collective heroism is more and more popular among people around the world and used as a special means of management in the enterprises of different fields. This paper aims to compare the cultural backgrounds and social influence of these two kinds of heroism in Shooter and Water Margin so as to improve the intercultural communication between Chinese and western people.
\end{abstract}

Index Terms - individual heroism, collective heroism, comparative study

\section{INTRODUCTION}

It is more than one hundred years since the first movie was invented. The invention of the movie was initially just a coincidence of an experiment, with its purpose to entertain people. In the past periods, with the rapid development of economy and the globalization of the coming era, movie industry as a big part in economy has developed a lot. Movies are not only an approach to enriching people's life but also a good way of culture exchange.

Nowadays, movies are more like a symbol of a culture than an entertainment. When it comes to American movies, a very interesting phenomenon attracts our attention, that is, many people swarm into the cinema. They are crazy for the commercial movies, especially those Hollywood movies of America, in which the Spider Man hovers above our heads and uses his supper power to save those people who are in trouble; the Bat Man fights with the evil to protect the whole city, and a group of ordinary people try their best to destroy a big asteroid which seems to hit our planet and at last save the whole world. These movies are all characteristic of individual heroism. As Transformers is introduced to our cinema, people can feast their eyes on those glaring stunts, but they seldom uncover the cultural backgrounds and general values behind the scene such as the individual heroism. For example, Shooter, as one of the typical American movie, on which this paper will focus, is also attracting many movie fans. Especially the shooter Bob Lee, who conquers many difficulties and defeats his enemies, at last, fascinates his fans with his amazing personality: typical American individual heroism. In Shooter, Bob Lee is a vivid character or a mirror reflecting the value of America. He is a perfect product of individual heroism. Compared with the individual heroism of America, the collective heroism rooted in Chinese culture is still fascinating many people. For instance, Water Margin creates one hundred and eight heroes working together to pursue their great dream. It also creates a heroic dream for Chinese.

With the acceleration of globalization, the world becomes smaller and smaller. The earth becomes a small village. The international communication becomes more and more frequent and comprehensive. Movies serving as the reflection of cultures and a good method to promote mutual communication are influencing many aspects of the world such as culture, economy, and environment. So to probe into movies from different cultures can be of great benefit to intercultural communication. This paper intends to compare the different connotation of heroism in Shooter and Water Margin, which can help us bring out the deep-rooted cultural values beneath the fantastic frames, thus improving people's understanding of different cultures.

\section{INDIVIDUAL HEROISM IN SHOOTER}

\section{A. The Definitions of Heroism and Individualism}

It is not an easy job to define heroism, for its meanings are so subtle and diverse that most definitions are dissatisfactory. On the basis of definitions given by scholars, it can be concluded as follows: A hero, in Greek mythology and folklore, was originally a demigod, the offspring of a mortal and deity, its cult being one of the most distinctive features of ancient Greek religion. Later, hero and heroine came to refer to characters who, in the face of 
danger and adversity or from a position of weakness, displayed courage and the will for self sacrifice - that is, heroism. Stories of heroism may serve as moral examples. In classical antiquity, hero cults - veneration of deified heroes such as Heracles and Achilles-played an important role in Ancient Greek religion. Politicians, ancient and modern, have employed hero worship for their own apotheosis.

As for individualism, its definitions are even more diverse. Researchers at the University of Michigan ever analyzed over 250 studies that investigated individualism, collectivism, or both (Oyserman, Coon \& Kemmelmeier, 2002). They found that the most relevant feature of individualism, as defined in the majority of the studies they reviewed, was valuing personal independence. Researchers at the University of Auckland in New Zealand point out that valuing personal independence involves putting an emphasis on personal responsibility and freedom of choice, personal autonomy, and achieving self-fulfillment. Moreover, individualists strive to maintain distinctive personal attitudes and opinions and prefer self-directed behavior and independence of groups. Individualists tend to see themselves as unique from others (Shulruf, Hattie \& Dixon, 2005).

\section{B. The Synopsis of Shooter and the Embodiment of Individual Heroism}

Shooter is a story of a top Marine sniper, Bob Lee Swagger, one of the world's greatest marksmen and the son of a Congressional Medal of Honoree, a loner living in the Rockies. He's left the military, having been hung out to dry in a secret Ethiopian mission a few years before, when he's recruited by a lisping colonel to help find a way that the President of the US might be assassinated in one of three cities in the next two weeks. He did his work, but the shot was fired notwithstanding and Bob Lee was quickly the fall guy: wounded and hunted by thousands, he went to ground and, aided by two unlikely allies, searched for the truth and for those who double-crossed him (Levison, 2002).

Shooter, as one of the typical heroic movies, has some features in common with other American heroic movies. In American heroic movies, there is always a superman, no matter what happens and how difficult the situation is, he will never give up, because nothing can scare or defeat him. It is a traditional rule of American heroic movies. In Shooter, Bob Lee, the protagonist who was cheated by the General but eventually reached the truth through many difficulties. In that movie, when Bob was chased by the FBI and the killers from the General, he did not give up although he was badly injured. He tried his best to find his friends to help him. Then he saved one FBI who became his supporter latter. He had a strong belief in himself that he could expose the truth at last. He had never given way in front of his enemies. Besides, those heroes in different Hollywood movies are always frustrated by various difficulties. It seems that the adversity really makes a hero. After struggling desperately, they can overwhelm the difficulties from outside and those pressures from inner side; just as the saying goes "when the going gets tough, the tough gets going" and this kind of heroes can always do things which are difficult or impossible for the ordinary people. Bob in Shooter, was circumvented and assassinated by the government after he finished his assignment. When he tried to kill the senator who had made hidden agenda in a farm, he was besieged by hundreds of armed soldiers. By killing almost half of them, he escaped from the encirclement. It is ridiculous and impossible for ordinary people to do this. While in the Hollywood movies it is just a piece of cake for those heroes. There were so many traps and conspiracies waiting for him, and it is adverse fortune for Bob, he did not give up himself in order to find the truth. Evidently, the progress of revealing the truth made his life at the risk and it was always a cliffhanger. Ultimately, he revealed all scheme of the government.

Actually, the individual heroism in American movies has several characteristics. First, most of the heroes are always considered to be the American soldiers, such movies as Pearl Harbor, Rambo, and Independence Day, for those heroes are always strong physically and mentally. Then all of them have one thing in common, that is, they do not belong to any group according to individualism. So in most of the heroic movies, the heroes are always a desirable dream of common people. In these movies, the characters all have a terrible experience which is a necessary background and factor for their success because "adversity makes a man wise and strong". Besides, they also have a special skill or supper power. For example, shooter Bob Lee is one of the best marksmen in the world. Apart from these, all the heroes in Hollywood movies are trying to be the embodiment of wisdom and courage, symbol of truth and justice. Those heroes are benefiting the whole society by punishing the criminals and dispelling the darkness. Shooter, as the typical American hero who lives in the society filled with crime and corruption, which is the political background of this story, has the strong responsibility for the society which encourages him to uncover the hidden agenda of the American government and then revenge for those victims, he does all he has to do as a hero of that time.

Obviously, when referring to individual heroism, it is easy to pick up their common values. The individual hero is not only a specific symbol in the movie to attract people attention, but also an embodiment of American culture. Peace, justice, love, and kindness are always considered to be the logo or embodiment of a hero. In the Hollywood movies, heroes are usually brave, wise, fearless, fair, strong, compassionate and persistent. Meanwhile, they are also a risk taker and good listener. Braveness or courage is the most important characteristic of a hero. Wisdom is a necessity for a hero, or he is just a giant with super power rather than a hero. That the shooter Bob fights against the powerful government is just like the sheep with his brave hearts facing the wolves. Just under such circumstances, the shooter makes use of his wisdom to find a FBI partner and achieves his success at last.

\section{Influence of Individual Heroism}

The influence of individual heroism is permeating every field. People who live in this kind of culture are all having a heroic dream in their mind. They do not want others to have a hand in or to meddle in their own personal affairs when 
they are doing their own work $(\mathrm{Xu}, 2003)$. Individual heroism is encouraging people to pursue democracy and freedom. It affects many aspects of Americans' life such as the way they are wearing or dressing, the education for little kids, the way they are acting in daily life and their ideas about family and marriage. They believe that they are a group of special people blessed by god; they have their own right to do what they want to do, because that is their special rights for "all men are created equal". Human rights and freedom are considered to be the symbols of this country. Individual heroism is encouraging people to stand up to fight for their own rights. In Shooter, Bob was a typical soldier who had affected a lot of American values; even faced with strong enemy he did not give up his pursuit, which was to uncover the truth in order to purge his criminal. In American's daily life, individualism plays a vital role. In their conversation, they prefer to show their own idea, and do not want other people to give suggestions or help. It is not polite to inquire about personal affairs, otherwise, it will be considered to be pushing your nose into other people's business. For the education of children, parents and schools are encouraging children to develop their creative abilities instead of shaping them into something or somebody (Luks, 2006).

People in individualistic cultures emphasize their successes and achievements in their jobs or private wealth. Especially in the U.S.A., the fight for jobs and climbing up in the hierarchy ladder are something very common there. In business, they try to improve their connections and gain more value out of them, not for establishing a good relationship but just for being involved in a calculative way. Employees are expected to defend their interests and to promote themselves whenever possible. So sometimes they are some kind of selfish, because they only focus on their interests and ignore others. It is a common claim that individualism represents the central feature of western civilization. Indeed, people in that society appreciate the idea that they are different from others. They aspire to autonomy and independence in their daily life and usually their own interests prevail over collective interests. So individualism really seems to embody a commonplace and resolute way of behaviors (Wootten et al, 2003).

According to these analyses, we can safely draw a conclusion that in western civilization, the individualism is rooted deeply in their culture. No person must think for others; thought is an attribute of the individual. One can start with the ideas of others, but each new discovery, each creative step beyond the already known, is a product of the individual. Individual does build on the work and ideas of others which is also an individual idea instead of the idea of the whole society. Those western heroes all have bravery, fortitude, wisdom, and superpower, and they are always preparing to bell the cat for other people. Heroes, from the Shooter Bob Lee to Rambo, are all the products of the individual heroism. They advocate the ability of individual instead of group. They are all doing their task in a perfect way by themselves instead of cooperation with others or asking for help from others. This kind of ideology has created many other Hollywood heroes in different movies.

The individualism affects economy and society too. For example, "Rising Tides" identifies the global-warming dangers created by our gluttonous use of energy resources. He suggests that it's impossible that Americans might consider some sacrifices to keep a viable environment for future generations. If Americans would stop driving their grossly oversized sport utility vehicles, it would be a step in the right direction. The idea that giving up such vehicles might be a "sacrifice" just shows how selfish and irresponsible Americans have become (Franklin, 2001). They focus too much on themselves, but little on other people or the next generation. Besides, they do not concern much with others' benefits. For instance, the whole world was threatened by the financial crisis, most of the countries were cooperating with each other and trying their best to escape from the abyss of suffering. While at this time the individualism is taking effect, in order to protect Americans' benefits, they began to slap tariff on the imports from other countries. Every coin has two sides, so does the individual heroism. It plays a good part in the development of America. Under the influence of individual heroism, American people are attending to be more personal and individual. We can seldom find out two Americans who are similar to each other in personalities, even for the twins. Just for this reason, it makes this country unique for inventions. Almost every important invention in this century has something to do with this country.

\section{Collective Heroism in Water Margin}

\section{A. The Definition of Collectivism}

Oyserman, Coon, and Kemmelmeier point out that the central ingredient of collectivism is the assumption that groups bind and mutually obligate individuals (2002). In their extensive review of literature, they found that collectivism is linked to a sense of duty to group, inter-dependence to others, harmony, and working with the group. Triandis asserts that in collectivistic societies, group goals have precedence over individual goals. Unlike the individualists, collectivists are emotionally connected to the in-group. A collectivist's values and beliefs are consistent with and reflect those of the in-group. Moreover, a collectivist's association with his or her in-group may last a lifetime. In many collectivistic cultures, the primary value is harmony with others. Just because group harmony is so highly valued, obedience to and compliance with in-group pressures is routine. One's behavior is role based, and deviations from the prescribed role are discouraged and often negatively sanctioned. In this sense, a person's behavior is guided more by shame than by personal guilt. A collectivist who stands out from the group disrupts the harmony and may be punished. Most collectivistic cultures value social reciprocity, obligation, dependence, and obedience. But by far, the primary value stressed by many collectivistic cultures is harmony (Triandis, 1990). 


\section{B. The Synopsis of Water Margin and the Embodiment of Collective Heroism}

Water Margin, as one of the four Chinese classic novels, has been adapted to a famous movie also named Water Margin or All Men Are Brothers. It has the same plots with the novel. In Water Margin, there were one hundred and eight people with different backgrounds and from different classes. Though all the characters had their own personalities which were totally different, they were living in the same society which was under the iron heel of the empire. They were driven to live in the water margin. Besides, they had the same tragic destiny. In their struggle for life and insurrection, numerous heroic stories were produced which won universal praise, such as tiger killing story in which the hero Wu Song killed a huge tiger just with his two fists and the story in which a group of people cooperated with each other to occupy the Zhu Family village by strategy. Water Margin is not only a story of loyalty but a presentation of collective heroism. Although these people were from different classes, some used to be rich while some others were poor, actually, most of them were from the bottom of the society. They were not entitled to a better life or could not enjoy basic human rights to pursue justice. Their lives were filled with darkness and exploitation. All they could do was to revolt against the empire. These factors provide a very good background for those heroic stories. Unlike American heroes who always have super power and can save the world, the heroes in Water Margin are not perfect ones. They were all ordinary people, and suffered a lot from the trifles of their life. Additionally, American heroes always fight with evil by themselves, while heroes in Water Margin had to be more collective and to obey the rules of their own group.

Water Margin is the turning point of Chinese heroism, before Water Margin, the definition or symbol of a hero is a man or woman (always a man) who sacrificed himself or herself in order to protect the motherland or the people. In that long period, there were just a few people who can be regarded as the heroes in people's eyes such as Wen Tianxiang and Yue Fei (both sacrificed their lives for the country's benefit). Later, the hero became a common symbol rather than a privilege of those special people. There were one hundred and eight heroes in Water Margin and each of them was unique, but when they were working in the big water margin, they had to obey the rules of that big family. They had to work with other people instead of working alone, and they also had to fight for all the people who lived in the darkness rather than for themselves.

When people refer to Chinese heroes, Water Margin can not be missed, because it reveals the typical collective heroism in Chinese culture. Collective heroism differs from individual heroism. In Water Margin, there is a very strange phenomenon that all the excellent heroes, who had one or more special skills, were willing to take order from the leader Song Jiang, who didn't excel in any physical skill. This will never happen in the culture of individual heroism. In China, the core of culture is the loyalty to the country or to the empire. The man, who shows loyalty to his country, the most sincere fidelity to his parents, the faith and loyalty to his friends, the sympathy for the poor and the strong conviction to justice, is considered to be the hero or the saint (Wang, 2005). In Water Margin the heroes were assigned to be on behalf of the gods to punish the tyrant, to comfort the people and to uphold justice. For the same purpose, different people with different backgrounds gathered in Water Margin in order to pursue their dream. Most of these people had ever done some bad things, such as killing travelers in order to get their money, or being chased by the government for the crimes they committed. When these people who lived at the bottom of the society were uprising to punish the tyrant, they were becoming the heroes who were on behalf of all the poor people.

Water Margin reflects the complete process of the beginning, development and failure of the peasants uprising in the later period of Chinese feudal society, reveals the broad vision of the social life at that time, exposes the darkness of the feudal society and the evils of the feudal rulers, excavates the social sources of the peasant uprising, brings to light the inevitability and justice of the peasant uprising, creates and extols a series of heroes who are fighting against the feudal oppression, writes out the tragic ending of the uprising of the Liang Shan, reveals the inner reasons for the failure of the uprising and the basic contradictions in the feudal society. Water Margin may be regarded as a solemn and stirring epic of peasant uprising of collective heroism.

\section{Influence of Collective Heroism}

Collective heroism plays a vital role in Chinese culture and affects the society a lot. Nowadays the loyalty to the people and the country, the most sincere fidelity to his parents, the faith and loyalty to his friends, and the sympathy for the poor and the strong conviction to justice are still prevalent in Chinese society. The collective heroism in Water Margin as one of Chinese philosophy plays a vital part in Chinese society and culture.

Nowadays, people are still judging and choosing friends with the rule of loyalty in Water Margin. A man who is loyal to his friends is considered to be the best friend just as the saying goes "the best friend is the one who can do everything for you". In Chinese culture, the rule that people should be loyal to his country, his friends, and his family has passed from generation to generation. During the anti-Japanese war those people who betrayed their country and helped those invaders were called traitors and regarded as the criminal of the whole people. Until now, loyalty to one's marriage is still looked upon as a virtue. Besides, fidelity to parents is the biggest part of Chinese culture. Old Chinese called themselves "land of ceremony and propriety". Being dutiful is the principle for all Chinese children. In Water Margin, Song Jiang, the chairman of Liang Shan, was a man who was respected by all the heroes for his sincere fidelity to parents. As for dutifulness, Chinese have many idols that play a big part in Chinese culture.

Nowadays, the values and spirits from Water Margin are advocated in company operation. Collective heroism is 
perfectly used. A big enterprise with hundreds of elites from various fields working together is running very well due to the influence of collective heroism. It is similar to the sixteenth interception story of Water Margin. In the atmosphere of collective heroism, every elite can make most of his ability and give his talent to full play, which differs from individual heroism culture in which only one hero can survive. China is constructing a harmonious society in which the collective heroism has been put into great play. In the harmonious society, everyone has his position, where he can show his talent. Everyone can be a hero in his own field. From the angle of collective heroism, the world cannot be saved by one person, or be operated by individual, for the entire world consists of different aspects, no one can be a generalist. The construction of the harmonious world needs cooperation among different countries. Collectivism has been rooted deeply in Chinese philosophy_Confucianism and Taoism. Confucius once said countries were always upon individuals, and in order to establish a powerful country, the empire should focus on the life of the people who were living in this country instead of his own life, just as the old saying goes "the most important thing for a man is to benefit the whole society". Led by this philosophy, Chinese people always regard the collectivism as their social values. Collectivism becomes the backbone of Chinese philosophy (Yuan, 2005).

\section{REASONS FOR DifFERENT CONNOtATION OF Heroism in Two MoviES}

\section{A. Cultural Background of Individual Heroism}

"Individual heroism of the sort dominant in America and many European nations, viewed overall, is a broad concept with complex roots going back into the deepest well springs of European civilization."(Emerson) Individual heroism is the core of American culture. The origin of individual heroism has been rooted in American religion, politics, and geographic position. Firstly, America is a country built by those Protestants who had escaped from the persecution of the Reformation. Those Protestants believed that it was unnecessary to have luxurious ritual, and every Christian was equal in front of god and they all had the right to have a direct connection with god rather than through the bishop, so all the human beings were created equal, even the King and the Queen were equal to their citizens. In Shooter, Bob Lee who believed all men were created equal struggled for his rights and freedom. Even faced with the threat of death, he did not give up. Anyone who has the superpower can save the world and the human beings are just like the super man and the bat man. This is the fundamental meaning of the individual heroism.

Secondly, the Declaration of Independence announced that "all men are created equal, that they are endowed by their Creator with certain unalienable Rights, which among these are Life, Liberty and the pursuit of Happiness." (Emerson) This statement emphasizes the individual right in the constitution, and provides a perfect evidence for individualism. In American history, the fights for human rights took up most of the time, such as feminism and the African-Americans' fight for civil rights. Then shooter Bob Lee is a paradigm of American individual heroes.

Besides, the geographic position of the United States plays a vital role in the emergence of individual heroism. America is located on an isolated continent surrounded by the Pacific Ocean and Atlantic Ocean, so they don't have much connection with other continents and countries. People's thoughts are also influenced by this kind of isolation. As the famous American writer Emerson said in his article "the union is only perfect when uniters are isolated...the union must be ideal in actual individualism." (Emerson) Just for this reason, they could focus on their development during World War I and II. The isolation of this country creates the individualism rooted in Americans' personalities. What's more, the frontiers went to the Westland which impressed people with loneliness and dangers. In order to survive in the barren land, those frontiers had to be brave and wise and depend on themselves. For example, the American frontiers had to develop the strength and self-reliance to survive in the Westland where civilization had not yet been established, laws and orders were weak, villains always preyed on the innocents. The process of the development of the Westland was also the process of the development of individual heroism. The triumph of good over evil justifies liberal politics, which relies on human self-reliance and independence.

\section{B. Cultural Background of Collective Heroism}

Compared with individual heroism, collective heroism also has been affected by specific philosophy, politics, and environment.

Firstly, collectivism has been affected by Chinese philosophies. Confucianism, Taoism and Buddhism are the core philosophies or religions of China, all of which teach people to think more about team work, harmony and loyalty. Collectivism emphasizes that the relationship between people should be harmonious. Such concept is demonstrated in such proverbs as "Two brains are better than one", "unity is strength" and "both together do best of all". In the classic Confucianism, people are required to be loyal to his country and people. Collective heroism also requires people to work together as a group rather than as an individual. In Water Margin the group of heroes were making their efforts to work together to pursue their dreams.

Secondly, the origin of collectivism has been rooted in Chinese politics too. China used to be a country of feudalism in which Confucianism played a very important role. It required people to ignore their own benefits in order to serve the country. Those heroes in Water Margin were affected by collective heroism and at last they had the same destiny.

Last but not the least, China is a big country with expansive territory, while the conditions are not very good for people's life. It is universally known that China is surrounded by many countries and most part of its land are deserts and mountains. Chinese people have to work together to fight for a better life. This kind of environment helps the 
development of collective heroism.

\section{A Comparison between Individual Heroism and Collective Heroism}

Collective heroism and individual heroism have something in common. Firstly, the Shooter Bob Lee suffers a lot from the government, while the heroes in Water Margin also suffer a lot from the governors and the tyrants. Those heroes, whether in Chinese culture or in American culture, have some similar backgrounds. They always live under the pressure of the government or society. Those heroes are created by the people living in the real world where they could not have a better life. Heroes are the reflection of the thoughts or the dreams of ordinary people, which they cannot realize in their daily life, such as hovering in the sky like a bat man, killing or punishing those people who used to offend them, overthrowing the tyrants and wiping the evil out of the earth like the spider man. Water Margin describes a society in which people were oppressed by the governors and the empire. In spite of this, the governors could not manacle people's thoughts, so they created those heroes in Water Margin in order to show their dissatisfaction and desire for a better life. Likewise, American people created the shooter Bob in order to show their feelings against the government. Secondly, heroes in Chinese movies or American movies have the same function to reveal ordinary people's dream of something or desire for something that they cannot achieve in their life. At last, all the heroes are characterized by the same qualities, such as loyalty, wisdom, courage, and justice. One of the most important factors is that almost every super hero has experienced many adversities which make them stronger than before, as the saying goes "the adversity really makes a hero." (Dewey, 1999)

Although there are many similarities between collective heroism and individual heroism, the differences should not be neglected. To begin with, collective heroism pays more attention to the cooperation among different people. It emphasizes that the society consists of many aspects and the harmonious society needs perfect cooperation or group work among different fields. As in Water Margin, although those heroes stood out with their unique skills, when they lived or worked in the big water margin, they had to obey all the rules, otherwise, they would get punished. For example, there was a story that Li Kui wanted to help the gentleman to find his daughter, but he made a mistake and broke the rules of water margin. Although his action was reasonable and the initiative was right, he was still punished by the rules. In contrast, the foundation of individualism lies in one's moral right to pursue one's own happiness. This pursuit requires a large amount of independence, initiative, and self-responsibility. People in individualistic cultures emphasize their success and achievements in job or private wealth and aim to reach more or a better job position. Especially in the U.S.A., it just counts to get there less caring who will leave behind one. In business they try to improve their connections and to gain more value out of them, not for establishing a good relationship but just to be involved in a calculative way. Employees are expected to defend their interests and to promote themselves whenever possible. The individual heroism always encourages people to show themselves and make most of their abilities. The shooter Bob Lee was in that kind of situation in which Bob Lee could make most use of his rights and resources to uncover the truth, for he lived in a country or society which focused more on people's freedom and rights. The individual heroism pays more attention to people's freedom and individual benefits rather than the community.

Besides, the two kinds of heroism contribute to different social influence. In the process of more than five thousand years' history, the Chinese government always advocates collective heroism. The core of Chinese philosophy is also collective heroism, and there are many proverbs describing them, such as "many hands make light work", "two heads are better than one" and "Great things may be done by mass effort" etc. Under its influence, many heroes come into people's life, such as the famous officer Kong Fanseng and the ordinary soldier Lei Feng, who sacrificed themselves to serve people and the country. Even today, the students whether in the primary school or in the university, are taught to learn collective heroism and implement them in their daily life. Likewise, individual heroism also has a big influence among American culture, value, people and society. One obvious influence among American's value is that, they are the ones who can save the world or can wipe the evil off. In the movie, shooter Bob Lee only depended on himself to fight against the evil which was impossible in the real world.

At last, the two kinds of heroism have different focus of attention. Collective heroism in Water Margin stresses group consciousness, harmony, emotional interdependence, obligation, and group solidarity. In contrast, individual heroism in Shooter emphasizes personal autonomy. For American individualism, everyone has his own independent personality and free will and others should not impose their will upon him except when individual interests endanger public interest. What's more, individualism means two aspects: pursuit of individual interests and bearing one's own responsibility at the same time.

\section{CONCLUSION}

Hollywood movies have earned a lot of money through the magnificent scenes and amazing special effects, meanwhile, American values and spirits are transmitted to the world. Among these movies, we can feel the earthshaking charm of individual heroism. However, with the rapid development of Chinese economy, the collectivism of Chinese culture is also increasingly attracting the whole world.

In recent years, as the global cultural crisis has become more and more serious, culture study has become a significant one. Movies become one of the most efficient ways to communicate with different people. Through the comparative study of Shooter and Water Margin, we can find that the excellent movies often reveal the most important 
cultural values of the host countries, which helps to propagate the native cultures and strengthen the influence of the culture. At the same time, appreciating the excellent foreign movies can help people to learn about different cultures and improve their intercultural awareness, which is sure to promote international communication.

\section{REFERENCES}

[1] Dewey, John. (1999). Individualism Old and New. New York: New York Publisher.

[2] Emerson, Ralph Waldo. Essay II-Self Reliance. http://wenku.baidu.com/view/18b46ffafab069dc502201df.html (accessed 27/10/2010).

[3] Franklin, Benjamin. (2001) .The Autobiography and Other Writing. Modern Language Journal, 5, 6-19.

[4] Levison, Ian. (2002). A Working Stiff's Manifest: A Memoir. New York: SoHo

[5] Lukes, Steven. (2006). The Semantic History of Individualism. Oxford: Basil Blackwell Publisher.

[6] Oyserman, D., Coon, H. M. \& Kemmelmeier, M. (2002). "Rethinking Individualism and Collectivism: Evaluation of Theoretical Assumptions and Meta-Analyses," Psychological Bulletin, 128,3-72

[7] Shulruf, B., Hattie, J., \& Dixon, R. (2005). "Development of a New Measurement Tool for Individualism and Collectivism," Journal of Psychoeducational Assessment, 25, 385-401

[8] Triandis, H. C. (1990). "Cross-cultural Studies of Individualism and Collectivism,” in J. J. Berman (Ed.) Nebraska Symposium on Motivation: 1989 (pp. 41-133). Lincoln: University of Nebraska Press

[9] Wang, Hongqing. (2005). New Thought about the Theme of Water Margin, Research on Novels of Ming and Qing Dynasties, 2 , 36-48.

[10] Wootten, David, et al. (2003). The Essential Federalist and Anti-Federalist Papers. Hakett Publishing Company.

[11] Xu, A'li. (2003). An Overview of Foreign Famous Movies. Sichuan: Sichuan Literature and Arts Press.

[12] Yuan, Xingpei. (2005). Chinese Literature History. Beijing: Higher Education Press.

Xiaohong Wei was born in Jianyang, Sichuan Province, China in 1971. She received her M. A. degree in Foreign Linguistics and Applied Linguistics from Sichuan University, China in 2004.

She is currently a professor in school of literature and law, Sichuan Agricultural University, China. Her research interests include intercultural communication as well as culture and translation.

Jian Xu is an English Major in school of literature and law, Sichuan Agricultural University, China. 